J. Environ. Sci.

Institute of Environmental Studies and Research - Ain Shams University

\title{
ENVIRONMENTAL FACTORS INFLEUNCING DISPUTED PATERNITY USING DNA-BASED METHODS
}

\author{
Heba G. Gabr( ${ }^{(1)}$; Sherien S. Ghaleb ${ }^{(2)}$; Hala I. Awadalla ${ }^{(3)}$ \\ Samia I. El Damaty ${ }^{(4)}$
}

1) Egyptian Forensic Medicine Authority, DNA unit, Medical Laboratory, Ministry of Justice 2) Forensic Medicine \& Clinical Toxicology, Faculty of Medicine, Cairo University 3) Medical Science Department, Institute of Environmental Studies and Research, Ain Shams University 4) Community Environmental and occupational Medicine, Faculty of Medicine Ain Shams University

\begin{abstract}
The paternity of a child may be disputed either when the child is born in wedlock and the husband denies paternity or when the child is born out of wedlock and the man named as the father denies paternity. There is great variation across cultures in beliefs about paternity, but cross-culturally, paternity confidence is positively associated with men's involvement with children and with investment or inheritance from paternal kin.

The study aims to focus on the role of DNA as powerful technology in disputed paternity and to determine the different environmental factors that predisposes to deny children.

DNA typing of 15 short tandem repeat (STR) loci included in the AmpF $\ell$ STR Identifiler TM PCR amplification kit (Applied Biosystems), was carried out on paternity cases arriving to Egyptian Forensic Medicine Authority (EFMA) - Medical laboratory with the use of questionnaire, this study was done during the period of one year, 48 cases fulfilled the criteria of this study with total 153 individuals.

Results showed that 23 of studied cases were inclusion cases (the alleged fathers "AF" are the true fathers) , 23 of studied cases were exclusion cases (the AF are not the true fathers) while the remaining two cases showed inclusion and exclusion within the same case.
\end{abstract}


The use of DNA in disputed paternity cases has a powerful role in determining inclusion/ exclusion. Also, results of this study showed the effect of disputed paternity cases on the children subjected to such situation.

Keywords: Amplification, DNA typing, disputed paternity, inclusion/ exclusion, short tandem repeat (STR).

\section{INTRODUCTION}

Forensic science is a broad term that encompasses a growing group of subspecialties in science and medicine, all of which convey fundamental methods. Medicine and law are related from the earliest times by the bonds of religion, superstition, and magic (Kharoshah et al., 2011). DNA typing has become the mainstay for forensic science as genetic polymorphisms are the most valuable tools for human identification and for determining genetic relationships. Therefore, DNA analytical technologies have irreplaceable position in the field of forensic science that resides within the core of justice system (Weir, 2003). The father of an illegitimate child is a man who acknowledges it or whose paternity has been established through judicial proceedings. A man who has adopted a child may also be its legal father. Legal paternity does not always equate to biological paternity, which is based on a true blood relationship. A biological father, as a result of procreation, transmits his genes to his child, which can be confirmed through DNA testing (Karpiewska et al., 2017). The number of ordered paternity investigations has increased considerably. Probably due to financial reasons in more and more cases only the putative father and the child are investigated. Moreover, very often only one method, such as STR analysis, is employed. This raises the question whether such a reduced analysis leads to reliable and clear results 
J. Environ. Sci.

Institute of Environmental Studies and Research - Ain Shams University

when investigating cases with related putative fathers (von Wurmb-Schwark et al., 2004).

Major important field of application of DNA typing is paternity testing and testing for relatedness on the maternal or the paternal lineage, DNA typing methods have increased the ability to solve problems of family relationships and forensic cases that might have otherwise been left unsolved (El-Alfy and Abd El-Hafez., 2012). When that does not occur and the birth certificate does not indicate the identity of the child's father, efforts may be made to establish fatherhood via court proceedings (Machado and Silva, 2012). There is great variation across cultures in beliefs about paternity, but cross-culturally, paternity confidence is positively associated with men's involvement with children and with investment or inheritance from paternal kin (Department of Anthropology, 2006). Results for a DNA paternity case are available in an average of 3-4 days from receipt by the most paternity testing laboratory. Cheek swab saliva testing can be done immediately after birth, and typically the child and alleged father are tested. Results exclude or confirm the biological father with an accuracy rate exceeding 99.99 (Hongbao et al., 2006). There is a growing awareness that a number of social and ethical issues arise from familial searching, so there is some hesitation about its use. Yet, within the sociology of the family there has been much debate over the role and significance of biology and genetics when considering what constitutes relatedness (Haimes, 2006). The tension between biological and social parenthood can be observed from two standpoints. First, the bond existing between the child and the persons who provide constant care to that child and with whom the child is emotionally attached is to be considered as 
relevant as the link with the biological parents. Second, whether or not biological parentage, if established, should carry with it a right to also enjoy a social relationship with the child (Steiner, 2006).

The aim of this is to focus on the role of DNA as powerful technology in disputed paternity and to determine the different environmental factors that predispose to deny children.

\section{SUBJECTS AND METHODS}

This study involved cases arriving to EFMA in the period between $1^{\text {st }}$ September 2016 to $31^{\text {st }}$ August 2017. All cases referred from court.

\section{Inclusion criteria of this study are:}

1- Cases from different governorates of Egypt.

2- At least Trio cases (father, mother and at least one child)

3- Disputed children from different gender.

\section{While exclusion criteria are:}

1- Cases with one missing parent.

2- Cases attending to fulfill governmental paper documents.

The total number of cases that arrived to EFMA in the mentioned period was 112 cases (families), 48 cases (families) \{with total 153 individuals (48 Alleged father, 48 mother and 57 child) $\}$ fulfilled the criteria and were included in the study, 64 were excluded from the study due to different causes: 23 the Alleged father attended, 14 the mother attended, 22 none of them attended, 5 cases (Child and mother only). 
J. Environ. Sci.

Institute of Environmental Studies and Research - Ain Shams University

Modified questionnaire was performed: Disputed paternity cases were subjected to questionnaire modified from CLIENT QUESTIONNAIRE PATERNITY GOLD LAW, A Professional Corporation -Camarillo, California (DCS, 2004), and CLIENT QUESTIONNAIRE - PATERNITY (Gold Law, 2013).

The questionnaire included different items some of which age/ education/ job of Alleged father / mother, the age / number of involved children, also issuing of birth certificate and receiving obligatory vaccines.

Sample preparation: Whole blood samples had been drawn into EDTA Vacutainer tubes from 153 individuals in the above mentioned for extraction, amplification and genotyping of 15 STR loci.

Extraction: Genomic DNA was extracted from withdrawn blood using QIAamp DNA minikit. The purified DNA was then used immediately or stored at $-20^{\circ} \mathrm{c}$ till amplification of DNA is performed.

Amplification: Extracted DNA was amplified according to manufacture instructions using AmpF $\ell$ STR ${ }^{\circledR}$ Identifiler ${ }^{\mathrm{TM}}$ PCR amplification kit. Amplify the samples using GeneAmp® PCR System 9700.

Typing: The PCR product will be detected using the Genetic Analyzer for 15 core STR loci as well as the amelogenin (sex determining) locus. Capillary Electropheresis and analysis of genetic fingerprint from Amplified samples (PCR) on 3130 Avant and 3500 instruments. According to AmpF $\ell$ STR®Identifiler manual. Results of all individuals in same disputed paternity case carried out by comparison to the reference allelic ladder included in the kit to determine the inclusion or exclusion of the Alleged Father. 
STR typing was used to study the 15 STR loci (D8S1179, D21S11, D7S820, CSF1PO, D3S1358, TH01, D13S317, D16S539, D2S1338, D19S433, vWA, TPOX, D18S51, D5S818 and FGA) in addition to a gender identification marker, amelogenin, by capillary electrophoresis Genetic Analyzer. For each locus, one fluorescently labelled primer pair was used [either 6-FAM (blue), VIC (green), NED (yellow) or PET (red)] (El-Alfy and Abd El-Hafez, 2012).

\section{Paternity and statistical analysis:}

Paternity analysis: refers to examine the genetic profiles of (alleged father, mother, child) and determine whether the alleged father is included or excluded as the biological father with assumption that the mother is the true biological mother, as well as ignoring DNA mutations.

Deterministic analysis: In deterministic paternity analysis, the trio data at each system is compared against a fixed rule, or set of rules. The comparison results in either a match or a mismatch between the child and the AF (Taymor, 2011).

In STR loci, the profile of each member of the trio at each locus includes two alleles. At each locus, the alleles of the mother and child are examined to determine which one of the child's alleles is the maternal allele. The other allele in the child's profile is the obligate paternal allele. A "match" occurs if the AF's profile contains the obligate allele. Otherwise, a "mismatch" occurs at this locus (Polesky, 2006). 
Statistical analysis: In this study, we will try to correlate the social level, educational level of alleged father and mother, gender of disputed child/ children. Comparisons were considered statistically significant of $\mathrm{P} \leq 0.05$.

\section{RESULTS}

This study included 48 disputed paternity cases arriving to the DNA lab at EFMA including 48 Alleged Fathers, 48 Mothers, 57 children giving total of 153 individuals.

23 of the cases showed exclusion of the child/children, 23 of cases showed inclusion of child/children while the remaining 2 cases showed inclusion and exclusion one case with 3 children ( 2 included and 1 excluded) and another case with 4 children ( 3 included and 1 excluded).

Table (1): The DNA Results of Disputed paternity cases

\begin{tabular}{|c|c|c|}
\hline DNA Result & $\mathrm{N}$ & $\%$ \\
\hline \hline Exclusion & 23 & $47.9 \%$ \\
\hline Inclusion & 23 & $47.9 \%$ \\
\hline Exclusion \& Inclusion & 2 & $4.2 \%$ \\
\hline Total & 48 & $100 \%$ \\
\hline
\end{tabular}


Table (2): Mean Age difference of Alleged Father/mother in disputed paternity cases

\begin{tabular}{|c|c|c|c|c|c|c|c|c|}
\hline \multirow[b]{2}{*}{ تِّ } & & & \multicolumn{4}{|c|}{ AGE } & \multirow[b]{2}{*}{ 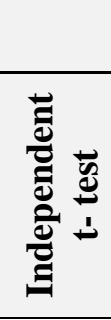 } & \multirow[b]{2}{*}{ 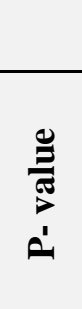 } \\
\hline & & $\mathbf{N}(48)$ & Mean & S.D. & Min & Max & & \\
\hline \multirow{3}{*}{ 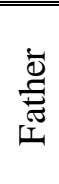 } & Exclusion & 23 & 41.26 & 8.843 & 30 & 62 & \multirow{3}{*}{2.767} & \multirow{3}{*}{.074} \\
\hline & Inclusion & 23 & 37.17 & 10.769 & 18 & 60 & & \\
\hline & $\begin{array}{l}\text { Exclusion \& } \\
\text { Inclusion }\end{array}$ & 2 & 52.50 & 6.364 & 48 & 57 & & \\
\hline \multirow{3}{*}{ 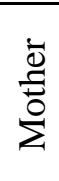 } & Exclusion & 23 & 30.26 & 6.566 & 17 & 40 & \multirow{3}{*}{1.562} & \multirow{3}{*}{.221} \\
\hline & Inclusion & 23 & 29.78 & 8.437 & 16 & 50 & & \\
\hline & $\begin{array}{l}\text { Exclusion \& } \\
\text { Inclusion }\end{array}$ & 2 & 39.50 & 2.121 & 38 & 41 & & \\
\hline
\end{tabular}


J. Environ. Sci.

Institute of Environmental Studies and Research - Ain Shams University

Table (3): Association between level of Education of Alleged Father versus mother and test results

\begin{tabular}{|c|c|c|c|c|c|c|c|c|c|}
\hline & \multirow{3}{*}{$\begin{array}{l}\text { Level of } \\
\text { Education }\end{array}$} & \multicolumn{6}{|c|}{ Test Result } & \multirow{3}{*}{ 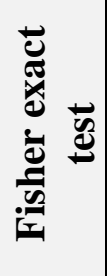 } & \multirow{3}{*}{ 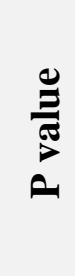 } \\
\hline & & \multicolumn{2}{|c|}{ exclusion } & \multicolumn{2}{|c|}{ inclusion } & \multicolumn{2}{|c|}{$\begin{array}{l}\text { exclusion } \\
\& \\
\text { inclusion }\end{array}$} & & \\
\hline & & N 23 & $\%$ & $\mathbf{N} 23$ & $\%$ & $\mathbf{N 2}$ & $\%$ & & \\
\hline \multirow{4}{*}{ 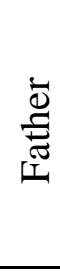 } & illiterate & 0 & 0.0 & 1 & 100 & 0 & 0.0 & \multirow{4}{*}{5.6} & \multirow{4}{*}{.57} \\
\hline & $\begin{array}{c}\text { Read \& } \\
\text { write }\end{array}$ & 11 & 57.9 & 8 & 42.1 & 0 & 0.0 & & \\
\hline & high school & 8 & 50.0 & 7 & 43.8 & 1 & 6.2 & & \\
\hline & university & 4 & 33.3 & 7 & 58.3 & 1 & 8.3 & & \\
\hline \multirow{4}{*}{$\begin{array}{l}\overline{\mathbf{D}} \\
\bar{\Xi} \\
\dot{\Sigma}\end{array}$} & illiterate & 3 & 42.9 & 4 & 57.1 & 0 & 0.0 & \multirow{4}{*}{5.1} & \multirow{4}{*}{.52} \\
\hline & $\begin{array}{c}\text { read \& } \\
\text { write }\end{array}$ & 13 & 59.1 & 8 & 36.4 & 1 & 4.5 & & \\
\hline & high school & 5 & 38.5 & 8 & 61.5 & 0 & 0.0 & & \\
\hline & university & 2 & 33.3 & 3 & 50.0 & 1 & 16.7 & & \\
\hline
\end{tabular}

$58 \%$ of university graduates in AFs showed inclusion of the children which was the highest \% among AFs, $61.5 \%$ of high school mothers showed inclusion of the children which was the highest.

Education level showed no significant difference between the two groups (exclusion/ inclusion). 
Table (4): Association between children with/without Birth certificates/ receiving obligatory vaccination schedule and disputed paternity cases

\begin{tabular}{|c|c|c|c|c|c|c|c|c|c|c|}
\hline \multirow{3}{*}{\multicolumn{2}{|c|}{ 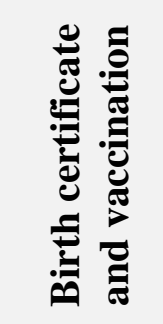 }} & \multicolumn{6}{|c|}{ Disputed Paternity Results } & \multirow{3}{*}{ 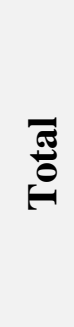 } & \multirow{3}{*}{ 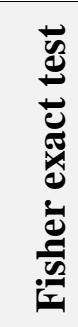 } & \multirow{3}{*}{ 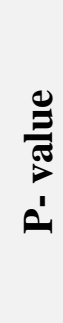 } \\
\hline & & \multicolumn{2}{|c|}{ Exclusion } & \multicolumn{2}{|c|}{ Inclusion } & \multicolumn{2}{|c|}{ 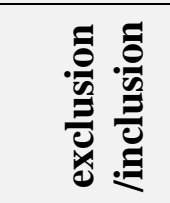 } & & & \\
\hline & & $\mathbf{N}$ & $\%$ & $\mathbf{N}$ & $\%$ & $\mathbf{N}$ & $\%$ & & & \\
\hline \multirow{2}{*}{ 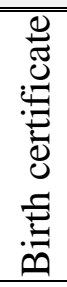 } & yes & 15 & 55.6 & 10 & 37.0 & 2 & 7.4 & 27 & \multirow{2}{*}{3.4} & \multirow{2}{*}{.18} \\
\hline & no & 8 & 38.1 & 13 & 61.9 & 0 & 0.0 & 21 & & \\
\hline \multirow{2}{*}{ 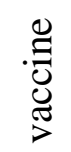 } & yes & 17 & 50.0 & 15 & 44.1 & 2 & 5.9 & 34 & \multirow{2}{*}{.93} & \multirow{2}{*}{.87} \\
\hline & no & 6 & 42.9 & 8 & 57.1 & 0 & 0.0 & 14 & & \\
\hline
\end{tabular}

Table (5): Association between Residence and disputed paternity cases

\begin{tabular}{|c|c|c|c|c|c|c|c|c|}
\hline \multirow{3}{*}{ 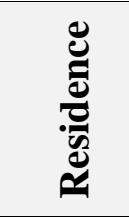 } & \multicolumn{6}{|c|}{ Disputed Paternity Results } & \multirow{3}{*}{ 흘 } & \multirow{3}{*}{ 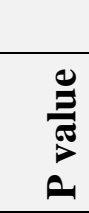 } \\
\hline & \multicolumn{2}{|c|}{ Exclusion } & \multicolumn{2}{|c|}{ Inclusion } & \multicolumn{2}{|c|}{$\begin{array}{c}\text { Exclusion } \\
\text { \& Inclusion }\end{array}$} & & \\
\hline & $\mathbf{N}$ & $\%$ & $\mathbf{N}$ & $\%$ & $\mathbf{N}$ & $\%$ & & \\
\hline Urban & 11 & 44.0 & 12 & 48.0 & 2 & 8.0 & 25 & \\
\hline Rural & 12 & 52.2 & 11 & 47.8 & 0 & 0.0 & 23 & \\
\hline
\end{tabular}


25 of the cases were from urban areas, 23 from rural areas. From urban areas $44 \%$ were exclusion, $48 \%$ were inclusion, $8 \%$ showed inclusion \& exclusion within the same family. While from rural areas $52.2 \%$ were exclusion, $47.8 \%$ were inclusion.

\section{DISCUSSION}

Different societies living in different conditions created different kinship and family structures with different rules for determining children's parentage. At the same time, biological paternity is significant not only in defining the rights and obligations of the biological father in respect to the child, but also in ensuring the child's right to know his or her parents, the right to preserve his or her identity, and the right of the child and the biological parents to respect for their private and family life. (Baumilè et al., 2016).

Exclusion in disputed paternity cases means that the child/or children are not the children of the AF while inclusion means that the child/children are the children of the AF.

The excluded cases showed variable number of loci excluding from as minimum as 2 loci in one case (the AF suspecting a son from $\mathrm{x}$-wife as a possible biological father of the child), maximum number of excluding loci was 12 loci in 3 cases.

The rate of mismatch for all STR loci deduced from excluded paternity cases involved in this study showed variability as follows D8S1179 13 (6\%), D21S11 18 (8\%), D7S820 16 (7\%), CSF1PO 11 (5\%), D3S1358 13 (6\%), TH01 12 (6\%), D13S317 9 (4\%), D16S539 16 (7\%), D2S1338 19 (9\%), 
D19S433 15 (7\%), vWA 13 (6\%), TPOX 12 (5\%), D18S51 22 (10\%), D5S818 $12(5 \%)$, FGA 20 (9\%).

In a study by Taymour (2011), she analyzed 121 trio Egyptian paternity cases, 61 showed inclusion (50.4\%) while 60 cases showed exclusion $(49.6 \%)$.

The births of almost half the world's children are not registered, leaving them outside support and protection systems and uncounted in policy decisions. UNICEF supports the right of every child to be registered at birth, without discrimination.

When a person does not have an officially established existence, there can be no birth certificate, no proof of age, no proof of biological parentage, no identification and no passport. Children with no birth certificate don't exist before the law, and are in danger of remaining on the margins of society, or being shut out altogether. They are more likely to face major challenges in accessing healthcare, education and social assistance.

Registration of children under 5 is almost universal in industrialized countries, but only half of children under 5 have their births registered in the developing world. Nearly two out of three children under 5 in sub-Saharan Africa and South Asia were not registered in 2007, with eight countries in these regions registering fewer than 10 per cent of their children. In comparison, in Latin America, 11 per cent of children under 5 were not registered, according to 2000-2008 data (UNICEF, 2013). 
In our study, $61.9 \%$ (13 of cases) the children included did not have birth certificates, 8 of the included cases $\& 6$ of the excluded cases did not receive the obligatory vaccines compromising $30.4 \%$ of the total not receiving obligatory vaccine which is a crime for the children \& community.

In a study in American University in Cairo (AUC), the age range of the male interviewees was 20-60, with the majority being in their thirties. Their level of education ranged from illiterate to a college graduate, but the majority held a secondary-level vocational degree. The jobs that they held included: carpenter, plumber, accountant, government employee, waiter, baker, factory worker, computer instructor, and teacher. The majority of the litigants' wives also held secondary-level vocational degree. Some of the jobs that the wives held included: outreach health care provider, cashier in a cafeteria, and a nurse. The marriages of all the interviewees were arranged by family members, neighbors, or friends. But it can be counter-argued that if his suggestion is implemented, litigation process in maintenance, child custody, and dispute of paternity cases will be prolonged, which will negatively impact women (Al-Sharmani, 2007).

\section{CONCLUSION}

The use of the autosomal fifteen loci (plus ameloginin loci) studied gave a very high value of disputed paternity cases studied with highest frequency in excluding with locus D18S51 10\%, and least in focus D13 S317 4\%.

The social status of the cases included in this study did not show significance in any of the included parameters as educational level or residence. 
$61.9 \%$ (13 of cases) the children included did not have birth certificates, $30.4 \%$ of the total not receiving obligatory vaccine thus it is recommended to encourage the intervention of responsible authorities as well as the unions of Human Rights for the sake of better health of the future generations.

\section{REFRENCES}

Al-Sharmani, M. (2007): The American University in Cairo Social Research Center, Recent Reforms in Personal Status Laws and Women's Empowerment "Family Courts in Egypt".

Alves,C.; Gusamo, L.; Pereira, L. and Aorim; A. (2003): Progress in Forensic Genetics,9, International Congress Series, 1239:131-135.

Baumilè, V.; Norvilienè, G.; and Šukys, E. (2016) Biological versus social paternity, International Judicial Cooperation In Civil Matters European Family Law, 2016.

Department of Anthropology (2006): Evidence from Worldwide Nonpaternity Rates. University of Oklahoma, 521 Dale Hall Tower, Norman, OK 73019, Current Anthropology Volume 47, Number 3.

El-Alfy S. H. and Abdel Hafez A. F. (2012): Paternity testing and forensic DNA typing by multiplex STR analysis using ABI PRISM 310 Genetic Analyzer, Journal of Genetic Engineering and Biotechnology 10, 101-112.

Haimes, E. (2006): Social and Ethical Issues in the Use of Familial Searching in Forensic Investigations, DNA fingerprinting \& civil liberties, journal of law, medicine \& ethics, 263-276.

Hongbao M.; Huaijie Z.; Fangxia, G. and Shen, C. (2006): Paternity Testing, Journal of American Science, 2(4), 76-92. http://dx.doi.org/10.4172/2157- 7145.S2-007. 
Karpiewska, A.; Kowalczyk, E. and Dobosz, T. (2017): Paternity testing at the Department of Forensic Medicine of Wroclaw Medical University (Poland), Journal of Legal Medicine 26, 18-24.

Kharoshah, M. A.; Zaki, M. K.; Galeb, S. S.; Moulana, A. A. and Elsebaay, E. A. (2011): Origin and development of forensic medicine in Egypt, Journal of Forensic and Legal Medicine 18,10-13.

Machado, H. and Silva, S. (2012): Issues on Methods of Identification in Court Ordered Paternity Testing -The Case of Portugal, Forensic Research, Machado and Silva, J Forensic Res 2012, $\mathrm{S} 2$.

Polesky, H. F. (2006): Parentage and relationship testing, in Molecular pathology in clinical practice, Leonard, D.G.B.(Ed.), Springer.

Roby, R. K. (2018): Identity analysis: Use of DNA analysis in parentage, forensic, and missing persons testing, pp. 1396- 1406.

Steiner, E. (2006): Electronic Journal of Comparative Law, vol. 10.3 http://www.ejcl.org.

Taymour, H. (2011): Combination of DNA-Based and Conventional Methods to Detect Polymorphism and Its Uses in Paternity Testing, M.D.Thesis, Faculty of Medicine, Al Azhar University.

UNICEF (2013): Child protection from violence, exploitation and abuse, UNICEF.org. Child protection home page. www.unicef.org.

Von Wurmb-Schwark N.; Malyusz, V.; Simeoni, F.; Oehmichen, M.; Lignitz, E.; Ludcke, C.; Repenning, A. and Poetsch, M. (2004): Paternity analysis in deficiency cases with related putative fathers: simulation of a deficiency analysis in 27 families, Arch Kriminol. Nov-Dec; 2014 (5-6): 173-83.

Weir, B. S. (2003): Forensic s, pp. 830-85. In Balding, D.J., Bishop, M. and Cannings, C. editors, Handbook of statistical Genetics, $2^{\text {nd }}$ Edition. Hoboken,New Jersey: John Wiley \& Sons. 


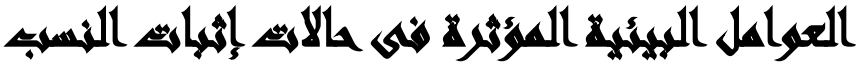

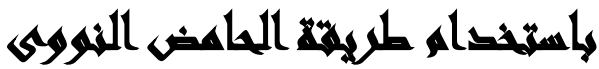

[1]

هبة جبالى محمد محمد جبر(')- شيرين صلاح غالب(")- هالة إبراهيم عوض اللها(")

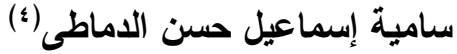

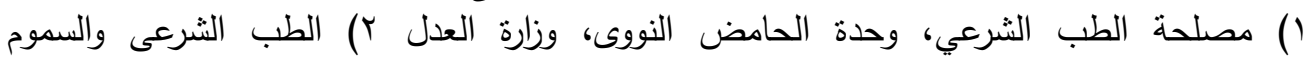

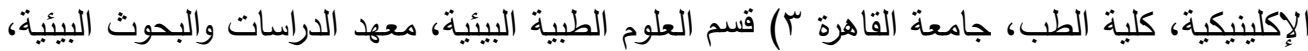

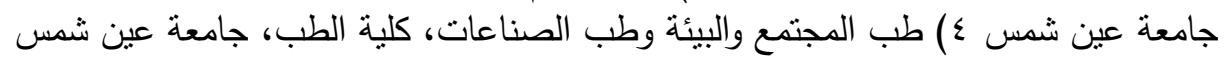

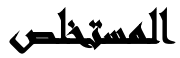

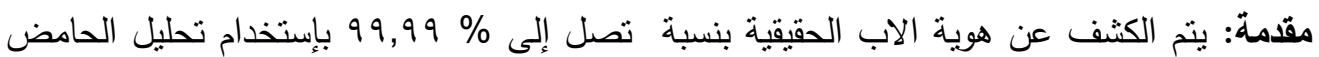

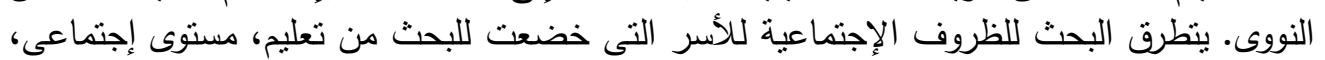

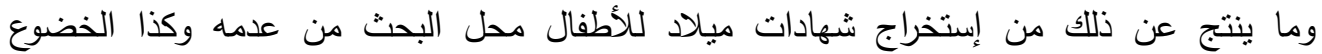

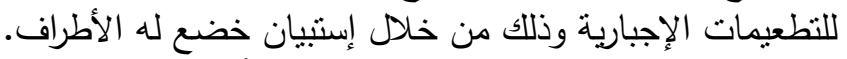
الهلف من البحث: يهدف البحث إلى دراسة أهمية الحامض لإلى النووى كوسيلة حديثة فى قضايا النسب وتحديد العوامل البيئية المؤثرة في قضايا إنبات النسب.

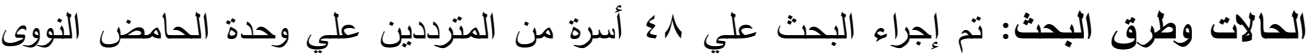

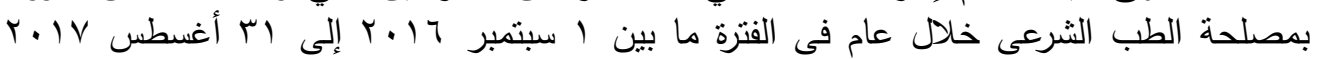

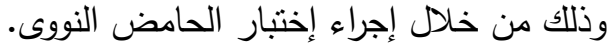

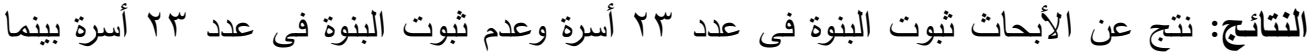
ثبت حالات بنوة وعدم بنوة فى أسرتين.

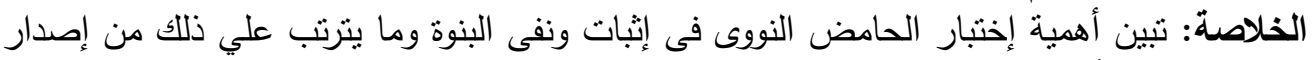
شهادات ميلاد وأخذ النطعيمات الإجبارية للأطفال موضوع النزات النزاع. الكلمات الادالة: إثبات / نفى البنوة، إختبار الحامض النوال مالنوى، الطب الشرعى. 